\title{
Article
}

|||||||||||||||||||||||||||||||||||||||||||

\section{Effectiveness of Electron Beam Microbial Decontamination and Change of Essential Oil Components in Fennel}

\author{
Rumi Yamaoki, Shojiro Kimura, Naomi Ohtsu, Yasuhiro Chiкuta, Kenji Aorı*, \\ Yoshiki Mino and Masatoshi Oнта** \\ Osaka University of Pharmaceutical Sciences \\ 4-20-1 Nasahara, Takatsuki-shi, Osaka 569-1094, Japan \\ * Japan Electron Beam Irradiation Service \\ 5-3 Kotsushima-cho, Izumiotsu-shi, Osaka 595-0074, Japan \\ **Faculty of Engineering, Niigata University \\ 8050 Igarashi 2-Nocho, Nishi-ku, Niigata-shi, Niigata Pref. 950-2181, Japan
}

Received November 28, 2007

\begin{abstract}
The effectiveness of electron beam (EB) disinfection and sterilization technology and the changes of essential oil components in fennel were investigated. The absorbed dose was maximal at a depth of $0.9-1.0 \mathrm{~g} /$ $\mathrm{cm}^{2}$, which was $130 \%$ of the surface dose of $15 \mathrm{kGy}$ in packed fennel irradiated with $5 \mathrm{MeV} \mathrm{EB}$ in a downward direction, and decreased in the deepest layer. As a result, in a fennel bacterial count of $10^{5} \mathrm{cfu} / \mathrm{g}$, a microbial contamination level below $1.0 \times 10^{3} \mathrm{cfu} / \mathrm{g}$ was obtained at a packing depth of $2.3 \mathrm{~g} / \mathrm{cm}^{2}$ and at the absorbed dose of more than $3 \mathrm{kGy}$. The bacteria in fennel were highly sensitive to EB irradiation. Furthermore, EB irradiation had no effect on the essential oil content of fennel, and no change of the essential oil components was found at the irradiation level necessary for decontamination.
\end{abstract}

Key Words : disinfection, electron beam irradiation, fennel, essential oil

\section{Introduction}

Fennel (Foeniculum vulgare Miller) contains essential oils, including anethole and estragol, and is prescribed as an aromatic stomachic in traditional Chinese medicine. It is also used as a spice. However, funnel contains bacteria between $10^{4}$ to $10^{6}$ colony forming units/gram $(\mathrm{cfu} / \mathrm{g})^{1,2)}$. Therefore, it requires the microbial control (below $10^{3} \mathrm{cfu} / \mathrm{g}$ ), set under standardized raw pharmaceutical materials on Japanese Pharmacopoeia $^{3)}$ or food additives on Food Sanitation $\mathrm{Law}^{4}$. The loss of volatile components of spices and aromatic pharmaceutical drugs by radio-sterilization causes few changes compared with heat treatment. Thus, the disin- fection and sterilization technology by irradiation is a useful method that prevents loss of the volatile compound in the aromatic essential oil of fennel. Especially, the exposure time of EB is shorter than that of gamma ray, because of the higher EB dose rate. In this study, the effectiveness of EB irradiation method for fennel as a technology for decontamination, and the changes in essential oil were investigated.

\section{Materials and Methods}

$2 \cdot 1$ Sample and EB radiation method

Fennel (whole size, $3 \mathrm{~mm}$, oval egg-shaped dry fruit; harvesting in Hokkaido) was obtained from a wholesaler in 2005.

The irradiation multilayer vessel was made 


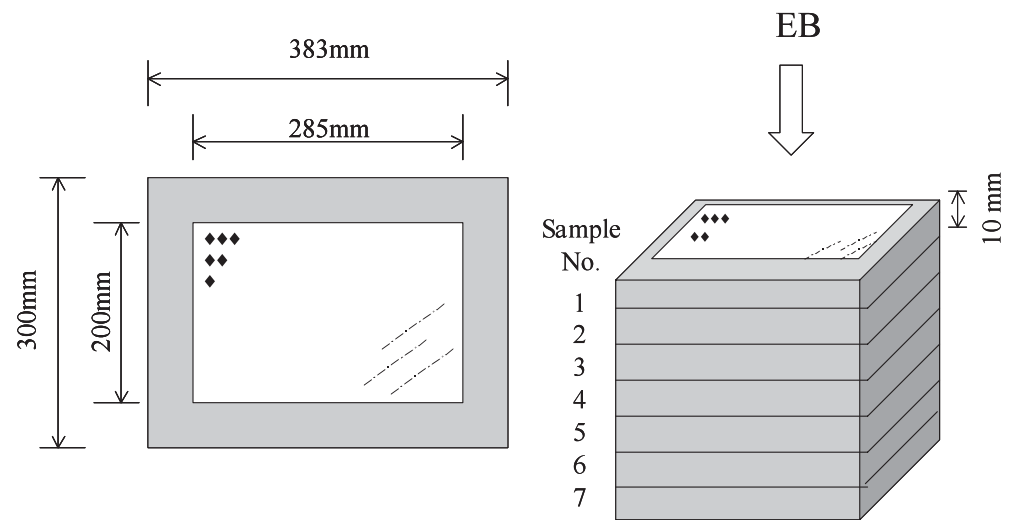

Fig. 1 Schematics of multilayer vessel developed for packing fennel and EB radiation. The frame of the vessel was made of foam polystyrene $(10 \mathrm{~mm}$ thick) and wrapped in polyethylene. Fennel was packed inside the vessel $\left(0.4 \mathrm{~g} / \mathrm{cm}^{3}\right)$. Multilayers of seven stacked vessels were irradiated with $5 \mathrm{MeV}$ EB in a downward direction (surface dose, $15 \mathrm{kGy}$ ).

of foam polystyrene $(10 \mathrm{~mm}$ thick; outer dimension, $300 \mathrm{~mm} \times 383 \mathrm{~mm}$; inner dimension, $200 \mathrm{~mm} \times 285 \mathrm{~mm})$ and the vessel was wrapped in polyethylene $(0.03 \mathrm{~mm})$, in shown Fig. 1. Fennel was packed inside the vessel (density, around $0.4 \mathrm{~g} / \mathrm{cm}^{3}$ ). Multilayers of seven stacked vessels filled with fennel (total depth density, around $2.8 \mathrm{~g} / \mathrm{cm}^{2}$ ) were irradiated with $5 \mathrm{MeV} \mathrm{EB}$ for the surface absorbed dose to become $15 \mathrm{kGy}$, which is fundamentally the same procedure as that reported earlier ${ }^{5}$.

Another plane sample (5 mm thick) was made for spreading fennel in polyethylene bags $(160 \times 100 \mathrm{~mm})$ and irradiated ranging from 1 to $20 \mathrm{kGy}$ to investigate radiation sensitivities of microorganisms.

\section{$2 \cdot 2$ Microbial limit test and identification of aerobic bacteria}

The number of aerobic bacteria in samples before and after EB irradiation was tested using the pour plate method ${ }^{6}$. Samples were pulverized using a compact tabletop grinder (Mr. Coffee). Addition of $1.0 \mathrm{~g}$ of powder to $10 \mathrm{~mL}$ of phosphate buffer ( $\mathrm{pH} 7.2$ ) was followed by soni- cation for 10 min in an ultrasonic bath. The suspension was serially diluted 10 -fold with the same phosphate buffer. Diluted solutions were poured into petri dishes $(\phi 100 \mathrm{~mm} \times 15 \mathrm{~mm})$, Soybean-Casein Digest Agar medium (Nihon Pharmaceutical) was added, then the two were mixed together. The plates were incubated for 5 days at $30-35{ }^{\circ} \mathrm{C}$. Tests were performed using at least three petri dishes for each dilution. Colonies of aerobic bacteria were counted for plates with counts of not less than 300 colonies.

For the purpose of identification of the bacteria species in the samples, petri dishes were filled with sample solution and media following the same method outlined above and were incubated for 1 day at $35{ }^{\circ} \mathrm{C}$. Morphologic characteristics of each colony were observed using a phase-contrast microscope (BX41, Olympus), and judged to be either gram-positive or-negative bacteria ${ }^{7}$. Each colony was then incubated for 1 to 3 days at $35{ }^{\circ} \mathrm{C}$, and tested using the BBL CRYSTAL identification kit (Becton-Dickinson $)^{8,9)}$. 

change of essential oil components in fennel

\section{$2 \cdot 3$ Essential oil determination}

$200 \mathrm{~mL}$ of water was added to $20 \mathrm{~g}$ of the multilayer sample in a 1-L flask and then heated to between $130{ }^{\circ} \mathrm{C}$ and $150{ }^{\circ} \mathrm{C}$ for 5 hours. The essential oil was extracted in $2.0 \mathrm{~mL}$ of xylene using apparatus designed for essential oil determination. Oil volume $(\mathrm{mL})$ was then measured at room temperature, and the volume of xylene was subtracted from the volume of the total oil to give the essential oil volume ${ }^{10}$. Measurements were performed two or three times, and the mean value was calculated from these results.

\section{$2 \cdot 4$ Volatile compounds for HPLC}

$0.5 \mathrm{~g}$ of powdered multilayer sample was added to $40 \mathrm{~mL}$ acetonitrile/water $(1: 1, \mathrm{v} / \mathrm{v})$, sonicated for $20 \mathrm{~min}$ then centrifuged (3000 $\mathrm{rpm}, 5 \mathrm{~min}$ ). The same method was repeated two times and the mixture solution of acetonitrile was added to the extracted solution to make $100 \mathrm{~mL}$. This solution was filtered with a membrane filter (pore size, $0.45 \mu \mathrm{m}$, Toyo) ${ }^{11}$. Separation and detection were carried out by the following method using a Shimadzu high performance liquid chromatography system (C-VP series) : injection, $10 \mu \mathrm{L} ; \mathrm{C}_{18}$ column (5C18-PAQ 4.6 $\times 150 \mathrm{~mm}$, Nacalai Tesque) ; mobile phase, acetonitrile/water $(1: 1, \mathrm{v} / \mathrm{v})$; column temperature, $30{ }^{\circ} \mathrm{C}$; flow rate, $1 \mathrm{~mL} /$ min; wave-length, $280 \mathrm{~nm}$. Calibration curves were prepared with standard solutions using analytical grade 1-methoxy-4-propenylbenzene (anethole, Wako), 4-methoxyallylbenzene (estragol, Tokyo Kasei Kogyo), and 4-methoxybenzaldehyde (anisaldehyde, Tokyo Kasei Kogyo), and each amount of the compound read using the absolute calibration curve method. Each quantitative determination was performed from three to five times and mean

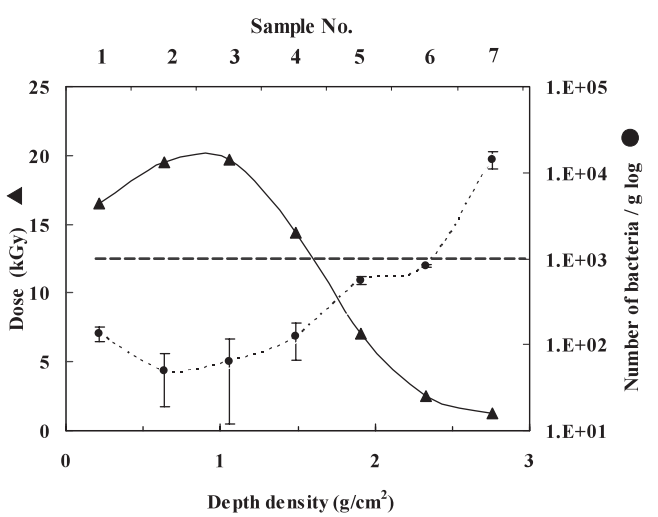

Fig. 2 Dose distribution and survived bacteria in multilayers of fennel after $5 \mathrm{MeV}$ EB irradiation.

values were calculated.

\section{Results and Discussion}

$3 \cdot 1$ Dose distribution in packing fennel and the bactericidal effect

Figure 2 shows the absorbed dose and the survived bacteria count in fennel of each layer exposed to $5 \mathrm{MeV}$ EB irradiation. As reported previously in the black pepper ${ }^{5}$, the absorbed dose for the packing depth of sample was maximal at $0.9-1.0 \mathrm{~g} / \mathrm{cm}^{2}$ density, which was 1.3 times the surface dose. The dose markedly decreased in the deepest layer.

On the other hand, the number of aerobic bacteria in Japanese-origin fennel was $1.1 \times 10^{5}$ $\mathrm{cfu} / \mathrm{g}$. Upon exposure to a surface dose of 15 kGy by $5 \mathrm{MeV}$ EB one-side radiation, bacterial survival count decreased below $1.0 \times 10^{3} \mathrm{cfu} / \mathrm{g}$ in the sample packed from the first to the sixth layers (depth density, $2.3 \mathrm{~g} / \mathrm{cm}^{2}$ ). Therefore, results reveal that decontamination levels required in raw pharmaceutical materials and food additives are obtained at a packing within a vessel depth of $5 \mathrm{~cm}$ in the fennel sample (whole fruit size, around $3 \mathrm{~mm}$ ). 
Table 1 Dependence on irradiation dose of survived bacteria in fennel

\begin{tabular}{ll}
\hline Dose & Spiecies \\
$\mathrm{kGy}$ & \\
\hline
\end{tabular}

Before irradiation Bacillus subtilis (38\%), Brevibacillus brevis (31\%), Bacillus pumilus (6\%)

3.2 Brevibacillus brevis (38\%), Bacillus megaterium (25\%)

$16 \quad$ Brevibacillus brevis (63\%)

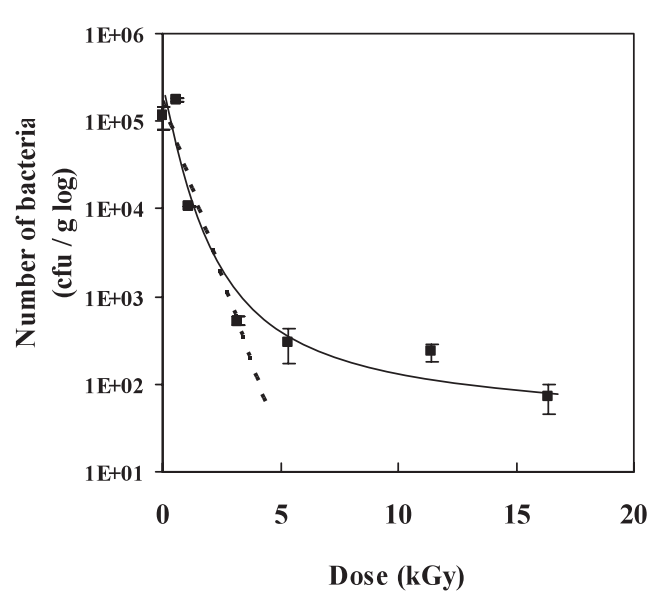

Fig. 3 Survival curves of bacteria in irradiated fennel.

$3 \cdot 2$ Radiation sensitivities of microorganisms

The survived bacterial strain list is shown in Table 1. The principal bacteria in the fennel were Bacillus subtilis and Brevibacillus brevis. Upon EB irradiation at $3 \mathrm{kGy}$, bacterial survival count was $5 \times 10^{2} \mathrm{cfu} / \mathrm{g}$, with Brevibacillus brevis and Bacillus megaterium detected. Exposure at $16 \mathrm{kGy}$ gave a survival count of $7 \times 10$ $\mathrm{cfu} / \mathrm{g}$, with Brevibacillus brevis detected. Figure 3 shows that the most bacterial strains in the sample are radiosensitive. The $D_{10}$ value was calculated by linear portion on semi-logarithmic graph (dotted line), approximately $1.3 \mathrm{kGy}$.
This result conforms to previous reports of $D_{10}$ values for Bacillus subtilis and Brevibacillus brevis $(1.4-1.68 \mathrm{kGy} \text { and } 0.58-2.0 \mathrm{kGy})^{12), 13)}$. The Survival Dose value (SD value), that is the required dose for decreasing the number of contaminated microorganisms to the target limit is calculated from the following (1).

$$
\mathrm{SD} \text { value }=\mathrm{D}_{10} \times \log \left(\mathrm{N}_{0} / \mathrm{N}_{\mathrm{SAL}}\right)(\mathrm{kGy})
$$

where, $\mathrm{N}_{0}$ is the number of microorganisms before irradiation and $\mathrm{N}_{\mathrm{SAL}}$ is the target limit value for the contamination of microorganisms. The SD value to meet the bacterium count below $10^{3} \mathrm{cfu} / \mathrm{g}$ was $2.7 \mathrm{kGy}$. Over $10 \mathrm{kGy}$, a small amount of bacterial survival counts were detected (below $0.2 \%$ of the total bacterial count). Some reports suggest that survival curves for microorganisms in irradiated spices and crude drugs tend to trail on at higher doses ${ }^{5), 14)-16)}$. The effect might be due to presence of a radioresistance component in plant tissue. The cause of residual microorganisms remains a matter of research.

\section{$3 \cdot 3$ Irradiation effects on essential oil com- ponents}

Essential oil content levels for Japanese fennel sample are shown in Fig. 4. The extraction volume of fennel was $1.1 \mathrm{~mL} \mathrm{(/20} \mathrm{g).} \mathrm{Post-irra-}$ 

change of essential oil components in fennel

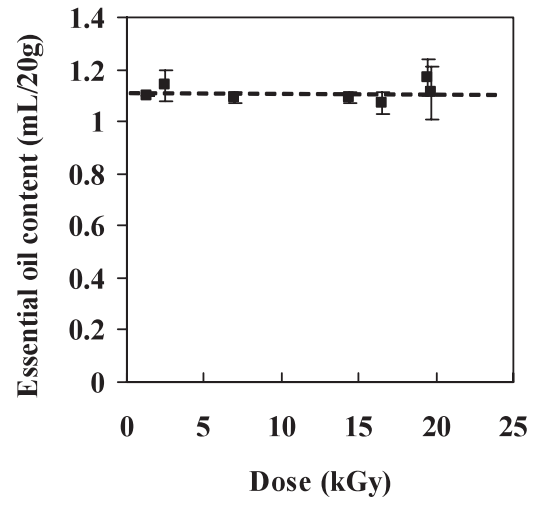

Fig. 4 Effect of EB irradiation on essential oil content in fennel.

Dashed line represents the level before irradiation.

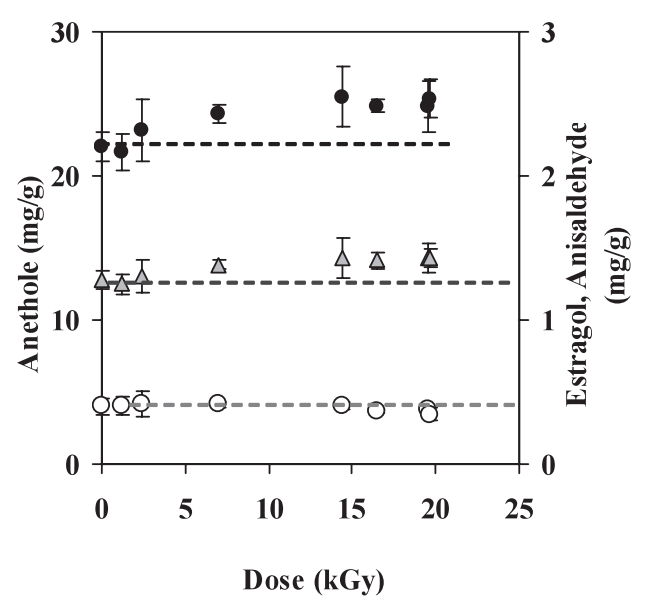

- Anethole $\Delta$ Estragol $\bigcirc$ Anisaldehyde

Fig. 5 Effect of EB irradiation on the volatile compounds in fennel.

Dashed lines represent each level before irradiation.

diation levels were also similar, and there was no change detected in the essential oil content level of fennel.

Figure 5 shows the analysis results for postirradiation essential oil components. The levels of essential oil components of fennel sample were as follows : anethole, $22.1 \mathrm{mg} / \mathrm{g}$; estragol, $1.27 \mathrm{mg} / \mathrm{g}$; and anisaldehyde, $0.4 \mathrm{mg} / \mathrm{g}$. These levels are similar as previously published results regarding essential oil component levels found in fennel cultured in Japan ${ }^{17)}$. Up to 14 $k G y$, the essential oil component levels showed an increase in response to the absorbed dose. Comparison with pre-irradiation analysis values, the post-irradiation levels had increased: anethole by $14 \%$ (relative standard deviation (RSD) , 5.3\% Ave.) , and estragol by $12 \%$ (RSD, $5.8 \%$ Ave.). An increase in extraction efficiency of essential oil components has been observed in gamma-irradiated black pepper ${ }^{18}$, resulting from radiolysis of the cell membrane. As in the case of irradiated black pepper reported, the cause of the post-irradiation increase in anethole and estragol lies in increased extraction efficiency. Anisaldehyde is a component of anethole oxidation. The analysis values for anisaldehyde showed no corresponding increase in essential oil component relative to irradiation dose. No significant results were forthcoming regarding anisaldehyde under our experimental conditions, as the relative error of the analysis value was $14 \%$ Ave.

On the other hand, HPLC analysis revealed the similar peak pattern both before and after irradiation, and had no appearance of new peak. Thus, any change in fennel essential oil components brought about by free radical increase due to sterilization dose of $\mathrm{EB}$ irradiation was below the level detectable by instrumental analysis.

\section{Conclusions}

The survival counts of packed fennel after 5 $\mathrm{MeV}$ EB irradiation on a surface dose $15 \mathrm{kGy}$ decreased to below a target limit of bacterial contamination for raw pharmaceutical materials $1.0 \times 10^{3} \mathrm{cfu} / \mathrm{g}$ at the packing depth of less than $2.3 \mathrm{~g} / \mathrm{cm}^{2}$ and at the EB irradiation dose of 
more than $3 \mathrm{kGy}$. Additionally, EB irradiation had no effect on the essential oil content of fennel, and no change of the essential oil component was found at the irradiation level necessary for decontamination.

\section{References}

1) Ando, S., Taniyama, T., Fukuda, Y., Kitagawa, N., Mirin, Y., Ishida, M., Kawakatu, Y. and Hayashi, T., Study on the application of electron beam sterilization to powdered crude $\operatorname{drugs}(\mathrm{I})$, Nat . Med., 53, 283-290 (1999)

2) Ito, H., Kamakura, H. and Sekita, S., Distribution of microorganisms in herb medicines and their decontamination by gamma-irradiation, Shokuhinshosha, 34, 16-22(1999)

3) The Japanese Pharmacopoeia Fifteenth Edition, Microbial Attributes of Nonsterile Pharmaceutical Products, Ministry of Health, Labour and Welfare, Tokyo, Japan (2007)

4) Food Sanitation Law, Standards for Food, Food Additives, Ministry of Health, Labour and Welfare, Tokyo, Japan (1959)

5) Yamaoki, R., Sasaki, T., Ishii, R., Okabe, H. and Kimura, S., Sterilization of black pepper by electron beam irradiation and identification of organic free radicals in irradiated sample by electron spin resonance, RADIOISOTOPES, 54, 365$373(2005)$

6) The Japanese Pharmacopoeia Fifteenth Edition., Microbial limit test for crude drugs. Ministry of Health, Labour and Welfare, Tokyo (2007)

7) Ryu, E., Kitasato Arch., Exp. Med., 17, 58 (1940)

8) Koshikawa, T., Microbiological method for radiation sterilization ( II ), Identification procedure of gram positive bacteria by using BBL CRYSTAL GP identification kit, RADIOISOTOPES, 53, 317$329(2004)$

9) Hironiwa, T., Yamamoto, Y. and Koshikawa, T., Microbiological method for radiation sterilization
(III), Development of identification software of spore-forming bacteria by using BBL CRYSTAL GP identification kit, RADIOISOTOPES, 53, 361$368(2004)$

10) The Japanese Pharmacopoeia Fifteenth Edition, Crude drugs test, Ministry of Health, Labour and Welfare, Tokyo (2007)

11) Iwasaki, Y., Suzuki, S., Yoshizawa, M., Ibuki, N., Aragane, M. and Hukuda, T., Quality valuation of Foeniculi fructus, Tokyo-to eiseikyoku gakkaishi, 104, 352 (2000)

12) Koshikawa, T., Sone, K. and Kobayashi, T., A simple identification method for spore-forming bacteria showing high resistance against $\gamma$-rays, RADIOISOTOPES , 42, 614-623(1993)

13) Ito, H., Ohki, Y., Watanabe, Y., Sunaga, H. and Ishigaki, I., Sterilization of bacillus spores by converted X-rays, Radiat. Phys. Chem., 42, 597-600 (1993)

14) Juri, M., Ito, H., Watanabe, H. and Tamura, N., Distribution of microorganisms in spices and their decontamination by gamma-irradiation, Agric. Biol. Chem., 50, 347-355 (1986)

15) Kimura, S., Taimatsu, M., Kodani, N., Ohnishi, T. and Okamoto, S., Radiation sterilization of the crude drugs Glycyrrhiza, Biocontrol Sci., 2, 87-92 (1997)

16) Katusin-Razem, B., Novak, B. and Razem, D., Microbiological decontamination of botanical raw materials and corresponding pharmaceutical products by irradiation, Radiat. Phys. Chem., 62, 261-275(2001)

17) Sato, M., Shimura, K., Hashizume, K. and Tanaka, K., Trial growing of Foeniculi fructus in Mie prefecture and quality valuation, Mie-hokenkankyokenkyu-nenpo, 48, 75-78(2003)

18) Tajima, M. and Hossain, T., Sterilization of commercial spices by gamma-ray irradiation and its effect to essential oil, Shokuhinsyosha, 24, 21-25 (1989) 
要旨

\title{
ウイキョウの電子線殺菌効果と精油成分への影響
}

山沖留美，木村捷二郎，大津尚美，筑田康裕，青木研二*，三野芳紀，太田雅壽**

\author{
大阪薬科大学 \\ 569-1094 大阪府高柣市奈佐原 4-20-1 \\ *日本電子照射サービス株式会社 関西センター \\ 595-74 大阪府泉大津市小津島町 5-3 \\ $* *$ 新潟大学自然科学系材料生産システム系列 (工学部) \\ 950-2181新潟県新潟市西区五十嵐二の町 8050
}

ウイキョウへの電子線（EB）照射による殺菌効果と照射後の精油成分への影響について調べた。 $5 \mathrm{MeV}$ の $\mathrm{EB}$ を片面照射した場合，ウイキョウ梱包試料に対する $\mathrm{EB}$ の吸収線量は，充填量 0.9 $1.0 \mathrm{~g} / \mathrm{cm}^{2}$ において表面線量 $15 \mathrm{kGy}$ の約 1.3 倍となる最大值を示し，これより深部の層になるほ ど減少した。その結果, 細菌数が $10^{5} \mathrm{cfu} / \mathrm{g}$ レベルのウイキョウでは, 充填量 $2.3 \mathrm{~g} / \mathrm{cm}^{2}$ 内, 吸収 線量 $3 \mathrm{kGy}$ 以上で殺菌レベル $1.0 \times 10^{3} \mathrm{cfu} / \mathrm{g}$ 以下に適応し， ウイキョウ試料中の細菌の $\mathrm{EB}$ 感受性 は大きかった。更に, 殺菌レベルの $\mathrm{EB}$ 照射による精油量への影響や精油成分の変化は見出されな かった。 